\title{
The Perception of Ecosystem Services in Public Sector Domains of Health, Tourism and Environment Protection in Croatia
}

\author{
Saša Poljanec-Borić
}

Institute of Social Sciences Ivo Pilar, Zagreb, Croatia e-mail:sasa.boric@pilar.hr

\section{Anja Wertag}

Institute of Social Sciences Ivo Pilar, Zagreb, Croatia e-mail:anja.wertag@pilar.hr

\section{Hrvoje Carić}

Institute for Tourism, Zagreb, Croatia

e-mail: hrvoje.caric@iztzg.hr

\begin{abstract}
In the article we analyze the familiarity with the concept of ecosystem services, perceptions of their various dimensions and attitudes to them. The target respondents were employees working in public institutions responsible for public health, tourism and environment and/or nature protection. Drawing on the COST project ToBeWell, a questionnaire was designed in order to find out how the concept was perceived within those institutions in several EU countries, including Croatia. The research carried out on a non-probabilistic sample in Croatia showed satisfactory familiarity with the concept within tourism and environment/nature protection institutions but unsatisfactory familiarity within public health institutions. Although the concept was perceived as relevant across all three institutional domains, the governance of ecosystem services and the cooperation in public health, environment protection and tourism were rated unsatisfactory.
\end{abstract}

Key words: ecosystem services, public health, environment, nature, tourism, policy, governance. 


\section{Introduction}

Ecosystem services are „benefits people obtain from ecosystems“ (World Resource Institute, 2005). Thus, „ecosystem services provide both the conditions and processes that sustain human life" (Salzman, 2006). Although there is a growing body of literature devoted to ecosystem services, it is still rather difficult to operationalize the concept. Notman et al. (2006) suggested that „ecosystem goods are generally tangible, material products that result from ecosystem processes, whereas ecosystem services are usually improvements in the condition of things of value". Boyd and Banzhav (2007) argued that ecosystem services are only the end products of benefit to human welfare such as a population of a certain fish or a soil formation. Lugo (2008) advocated a clear definitional distinction of ecosystem and environmental services due to the economic value of the services. If ecosystem services are synonymous with environmental services, people may have to pay for these services, including water services, which should be free (Lugo, 2008 cited in: Blanco and Razzague, 2009:694).

The conceptual framework developed by Pearce (2007) stressed that supply and demand relationship is essential in understanding the economic "side" of ecosystem services. Within his conceptual framework two types of ecosystem services: marketed and non-marketed are distinguished. Marketed ecosystem services such as timber or fuelwood or scenic landscapes are associated with already established markets in which formal exchange takes place. On the other hand, non-marketed ecosystem services such as watershed protection, carbon sequestration and storage, scientific knowledge, the aesthetics of natural ecosystems are hard to appropriate. Thus, two different demand curves can be identified: one for the marketed ecosystem services and another for all ecosystem services, regardless of whether they currently have markets or not. Pearce (2007:316) further argued that, historically, ecosystem services have been abundant. Hence, there has been only a limited incentive for humans to establish property rights over them. As global population expanded and humans intervened in virtually all terrestrial ecosystems, there is an incentive to establish property rights because ecosystem services become scarce relative to human demands on them ${ }^{1}$ and relative to the increasing extinction record of biodiversity (Pearce, 2007:318). The growth of appropriation rate leaves no doubt that the marketization of all ecosystem services is increasing and that ecosystem services obey the "law of demand". Should humans continue to increase the contingent of marketed ecosystem services, it should be rational to expect the under-provision of all ecosystem services (Pierce, 2007:317). This would increase the willingness to pay for one ecosystem services but one more unit would become extremely high, thus leading whole humanity into the danger of extinction (Pearce, 2007:316). Fisher et al. (2008) suggested that, if consumed or utilized by humanity either directly or indirectly, ecosystem services included ecosystem organization (structure), operation (process) and outflows, with direct impact on human welfare. In order

$\mathbf{1}$ Humans have appropriated around a third to a half of the net primary product (NPP) (Vitousek 1986; Vitousek et al., 1997 cited in Pearce, 2007:316). 
to facilitate the delineation between direct and indirect consumption of ecosystem services Fisher et al. (2008) proposed intermediate and final qualifiers as used in conventional economic accounting, thus stressing inclusive consideration of final services and benefits. Both types of ecosystem services are of interest for economics even though most ecosystem services are nonmarket services (public goods) whose benefits should not be monetized but captured through some type of institutional arrangement (Fisher et al., 2008:2053).

The key message of Pearce's (2007) analysis was that global concern about economic dimension of ecosystem services should increase due to the increasing appropriation and extinction problems related to all ecosystem services. Fisher et al. (2008) further developed this position by stressing that a greater focus on the research of the concept of marginality and/or ecosystem transition states and of structure and function needed to produce a sustainable flow of services should be in place if the fundamental uncertainty regarding the minimum level of ecosystem structure needed to provide a continual flow of services (Fisher et al., 2008:2053) is to be addressed. In such a perspective the distribution of ecosystem services across the landscape should be of interest for economics in the world committed to market economy and the "law of demand".

Undoubtedly, the problem related to distribution of ecosystem services provision and use across the landscape is extremely policy relevant due to the fact that it affects not only human welfare in general but also tourism performance and human migratory dynamics on local and regional levels. Already in 2005 island Phuket in Thailand suffered serious financial losses in tourism and hospitality industry due to unpredictable episodes of natural cataclysms such as tsunami ${ }^{2}$ while in 2012, 32.4 million people were displaced because of natural disasters (Gemmene, Brükner and Ionesco, 2013). In such circumstances institutional awareness about the ecosystem services provision and distribution is growing around the globe (Ruijs, van Egmond, 2017). Also, governance of ecosystem services becomes increasingly relevant research topic (Primmer et al., 2015). However, paradoxically the literature devoted to this topic is mostly devoted to ecosystem services in urban landscape (Haase, Frantzeskaki and Elmquist, 2014).

Therefore, many challenges remain in common understanding on what ecosystem services are; what are adequate quantification methodologies (Boerema et al., 2017); and ultimately how the knowledge that is generated by this conceptual framework can impact decision making (Posner et al., 2016). In the analysis of gaps of 68 tools for integrating ecosystem services into decision making, Grêt-Regamey et al. (2017) indicated that sectors such as agriculture or forestry have integrated much strongly ecosystem services in their decision making while efficient tools are lacking to link

2 The tsunami's impact on the tourism industry on the island has led to the closure of over 400 hotels, restaurants and souvenir shops, leaving over 5,000 people unemployed (Cf. The Nation: „POST-TSUNAMI TOURISM: Phuket struggles to reverse slump. Published on June 27, 2005) 
land use policies with cultural services or services supported by soils. Besides bridging the gaps in the science-policy interface and the need to understand decisionmaking processes, there are implementation design issues to be considered that would prevent commodification of ecosystem services and unsustainable practices. A study of Payment for ecosystem services practices in Indonesia, the Philippines and Nepal, stress that simultaneously fairness and efficiency must be considered in design and implementation (Leimona et al., 2015).

In order to fill the gap in the literature and to find out to which extent are various institutional actors across EU familiar with the concept of ecosystem services a research was designed in 2015 and conducted in 2016 within the COST action IS 1204 TObeWELL - Tourism, Wellbeing and Ecosystem Services ${ }^{3}$ by the working group established for the purpose of institutional analysis of the relation between tourism, ecosystem services and public health across EU countries (COST, 2012). The relevancy of the research was confirmed by the ubiquitous presence of public institutions for monitoring and/or regulating environmental protection, public health and tourism in all countries participating in the project.

\subsection{Research setting}

Considering the purpose of the COST Action ToBeWell, Croatia seemed as an ideal country for the institutional analysis of the relation between tourism, ecosystem services and public health across EU countries. Croatia has a long lasting public health protection tradition, unique natural capital and a fast growing tourism industry coupled with constant raise of the quality of tourism offer and growing pressure on the appropriation of public spaces, public goods and ecosystem services (PoljanecBorić, 2016). Last but not least, as a part of the accession process to the EU the country underwent substantial normative adaptation in the period 2004 - 2013, a fact that should suggest acceptance of EU commitments to the environmental protection and nature conservation.

\subsubsection{Public health}

Croatia has well developed network of public health institutions with strong tradition. Public health protection policies were implemented in the country due to the pioneering activities of Andrija Štampar who developed his public health principles during the First World War. In that period he became acquainted with the health problems of rural populations while he served as a medical doctor in rural communities across Croatia. After the First World War he championed in organizing campaigns against epidemic diseases which is why he was able to establish, with the support of the Rockefeller Foundation, the School of Public Health in Zagreb

3 This COST action started on October 22, 2012, and lasted until April 20, 2017, and more details about the action are available on the website: www.tobewell.eu 
already in 1927. In the course of time this school became a postgraduate medical training center in which particular emphasis was laid on special training in social medicine and hygiene (Cvjetanović, 1990). Today the School in the part of University of Zagreb School of Medicine while its mission is: “... to develop top experts, methods and standards in the field of public health, with the aim of raising the level of health of the population by means of scientific research and professional activity, graduate and postgraduate training and continuous education programs" (University of Zagreb, 2017). The very mission of the School is coupled with the activities of 21 county institutes of public health which are protecting and monitoring public health across Croatia. Also, during the accession to the EU, Croatia incorporated into national legislation most of the requirements of the Acquis Communautaire even though "there is lot of work and effort needed to upgrade the environmental health services and other management instruments in order to be in position to implement the high level standards under the acquis requirements" (Capak and Petrović, 2009). National Health Care Strategy (Ministry of Health, 2012) stated that only 10\% of favorable 222 locations is used in medical tourism thus suggesting an intent of advancing further linkage of tourism with both public and commercial health services (i.e. tourism). Currently, already dozens of hotels offer wellness and medical related treatment. This trend is in Croatia further assisted by the Ministry of health which has in 1998 designated the sixty year old Thalassotherapy as Reference Centre for Healthcare Tourism and Medically Programmed Recreation. Complementary, Ministry of tourism has published in 2014 a National Action Plan for Development of Health Tourism. Given the described context, it seems that the research aiming at assessing the familiarity and awareness with ecosystem services within this public health system of institutions in Croatia is timely and could be of interest for policy makers in this particular domain.

\subsubsection{Natural capital / environment}

Environmental protection and nature conservation has a long history as initial ideas of nature protection in Croatia appeared near the end of the $19^{\text {th }}$ century. In the first half of the $20^{\text {th }}$ century provisions related to nature protection were integrated in many laws. The 1960 Nature Protection Act enabled an independent nature protection service to be formed. Subsequent Nature Protection Acts proclaimed in 1976 and 1994 prescribed the more important role of public institutions such as national and nature parks thus increasing the efficiency of protection in parks. The Nature Protection Directorate has been an integral part of the Ministry of Culture since 2004. In 2011 the management of nature conservation has been taken over by the Ministry of Environmental and Nature Protection (MENP, 2017). Nowadays, Croatia has a fully developed stakeholders from legislative segments (i.e. ministry, agencies, regional branches, etc.), and expert segments (i.e. private companies, institutes, expert NGOs, etc.). However, many challenges remain and they will become more visible after a period of being an EU member elapses and legislative implementation is assessed by European Commission. Tourism impacts on human and environmental health are directly related to the abilities of formal environmental management to deal with issues of waste, wastewater, consumption of water and electric energy etc. 
On the other hand, the perception of the environmental status determines the attractiveness and competitiveness of the destinations. General estimates are that 20\% of the global travel is primarily motivated by beauty of nature. Research in Croatia confirms the significance of nature as a travel motivator and continuously shows high levels of satisfaction with scenic nature (Institute for Tourism, 2015). Biological and landscape diversity are therefore the foundations of the Croatia's tourism attractiveness. In the European context, Croatia sticks out by the fact that it occupies four biogeographic regions (only very few have more than two) with sixteen landscape types, holds third EU rank number of plant species per area, and is also third in Mediterranean in the fish diversity (Ozimec, 2014). Croatia's NATURA 2000 network $^{4}$ covers $36.5 \%$ of the territory what is double the EU average. Therefore, environment protection is an important activity in Croatia which substantially underpins not only the protection of the environment but also the preservation of the resources vital for brand identity of Croatia's tourism.

\subsubsection{Tourism development and trends}

Modern tourism in Croatia started in $19^{\text {th }}$ century (Vukonić, 2005) with the construction of the accommodation capacities that were designed to receive larger number of people. As early as 1914 Opatija, one of the most prominent destinations of that time, have had over one million overnights. Between the two World Wars the development continued and by 1938 the peak was reached with the record of 2.7 million overnights of which significant proportion was realized by domestic tourists. The period until the end of fifties in $20^{\text {th }}$ century saw decline in organized tourism and small scale private accommodation started to emerge. The communist Yugoslavia embraced the mass tourism sun and sea tourism concept in the sixties' and intensified development of coastal destinations. The peak was reached in the late eighties' of $20^{\text {th }}$ century with 68 million overnights and 10, 5 million of tourist arrivals. Those numbers diminished to a fifth during the War for Independence in 1990 - 1995. As of 1997, after the peaceful reintegration of eastern Slavonia, Croatia managed with time to reposition its image from little know Yugoslav republic to a globally recognized macro-destination. Recently, communication channels such as: Lonely Planet, Reuters, Google analytics and others declare Croatia to be a leading world destination by their parameters.

When it comes to basic tourism statistics Croatia's rank in travel and tourism competitiveness is 32 out of 136 countries (WEF, 2017). Also, Croatia has the highest dependency from tourism within the EU. Internal tourism consumption is $9.4 \%$ of domestic supply while Spain's is 5.7\% (Ivandić and Marušić, 2017). The most recent book on the state of the tourism in Croatia (Dwyer et al., 2017) describes key challenges in tourism and it can be concluded that they persist generally due to:

4 Natura 2000 network is the biodiversity network of protected areas in EU that allows for more efficient management through coordination and synergy. http://ec.europa.eu/environment/nature/natura2000/index en.htm 
- fragmented planning process, lack of political consensus and poor coordination among governmental bodies (Kunst, 2017);

- lack of political will and related resources to establish efficient destination management (Čorak and Boranić Živoder, 2017) and also to capitalize on the existing network of local and regional offices of the tourism board;

- existing tourism and spatial planning system do not sufficiently consider resource attractiveness and its related potentials in sustainable tourism (Kušen, 2017);

- often chaotic land zone planning as the consequence of: transformation from centralized-communist to market economy coupled with the complexity of issues and regulations that has to be considered (Kranjčević, 2017);

- practices of analytics of contribution of tourism to the Croatian economy. Although tools and capacities exist, the contribution is not continuously nor frequently measured also without sufficient focus on the regional/county scale (Ivandić and Marušić, 2017);

- slow adaptation to the emerging new demand that is based on the sizable population of consumers that place emphasis on the health, environment and local community (Dwayer et al., 2017).

Increased need for monitoring environmental side of tourism expansion in Croatia is also suggested in a document such as "Tourism - Sectorial pressures indicators" (Cro. EPA, 2008). On the other side, government ministries and agencies showed progress of legislative effort in that direction as they now formally include or demand more visible consideration of issues pertaining to the natural capital and ecosystem services through Action Plan for Development of Green Tourism (Ministry of Tourism, 2016) and Strategy and Action Plan of Nature Protection (GOC, 2017). Therefore, it is obvious that in the case of tourism governance in Croatia the research of familiarity with ecosystem services is also highly relevant.

\subsection{Research objectives and hypotheses}

Meta-presumption of the research was that there were some public sector domains within EU countries which will first encounter the ecosystem issues within their routine professional activities (COST, 2012). Therefore, the objective of the research was to analyze whether professionals employed in specifically chosen different public sector domains (i.e. environment, public health and tourism) in various countries participating in the research differ in:

- Familiarity with ecosystem services

- Perceptions of importance of ecosystem services

- Perceptions of the quality of cooperation between three domains

- Attitudes about the level of authority responsible for implementation of policies on ecosystem services

With such research questions in mind, the following hypothesis were tested in Croatia, on the sample of respondents working in public health, tourism and nature protection public sector domains: 
H1: Respondents' institutional affiliation affects the familiarity with ecosystem services in a way that respondents from public health and nature protection will be more familiar with ecosystem services than respondents from tourism domain.

H2: Respondents' institutional affiliation affects the perception of relevance for work of ecosystem services.

H3: Respondents institutional affiliation affects the perception of importance of specific ecosystem services.

H4: Respondents institutional affiliation affects the perception of allocation of governance responsibility for ecosystem services.

H5: Respondents will rate current level of cooperation between three public sector domains in Croatia as unsatisfactory.

H6: Respondents from the nature protection field will favor higher level of authority (i.e. EU) when it comes to governance of the Ecosystem services policies, while the respondents from the other fields will stick to the national level.

\section{Methodology}

The study consisted of two phases: in the first, qualitative phase, interviews were conducted with representatives of high officials of each of the three public sector domains in Croatia: Ministry of Tourism and Ministry of Environment and Energy and in the Institute for Public Health. The main purpose of these interviews was to acquire deeper insight into the quality of perception of ecosystem services within targeted institutional setting in Croatia.

After running a qualitative research, members of the working group designed the questionnaire. The questionnaire had to be applicable in all countries participating in the research. Therefore a list of ecosystem services that were found to be present in the enclosed farmland as a broad habitat by Smith et al., (2013) was chosen as appropriate. Those ecosystem services were: a) food, b) fibre, c) biofuels, d) fresh water, e) climate regulation, f) pollution control, g) water quality regulation, h) pollination, i) disease and pest control, j) recreation $\mathrm{k}$ ) aesthetic values, 1) cultural heritage, $\mathrm{m}$ ) education, $\mathrm{n}$ ) sense of place. The questionnaire was divided in three major parts where familiarity with ecosystem services, perceptions of importance of ecosystem services within institutions regulating tourism, public health and nature protection and attitudes about the levels of governance responsible for implementation of policies of ecosystem services were of specific interest. The research was launched in five countries and conducted online in March and April 2016 in Croatia, Poland, Bulgaria, Denmark and Lithuania via same questionnaire originally constructed in English and translated in the on line version in Croatian, Polish, Bulgarian and Lithuanian while respondents from Denmark used English questionnaire. The dissemination of the questionnaire was overlooked by the working group members 5

5 Working group members that overlooked research in their respective countries were: Dr. Anna Dluzewska (Poland); Dr. Stella Baltova (Bulgaria); Dr. Ieva Misiune (Lithuania); Dr. Anne-Mette Hjalager (Denmark); Dr. Saša Poljanec-Borić (Croatia). 
participating in the research, while the central collection of the data for all five participating countries was overlooked from the University of Zagreb (Croatia) computing center SRCE.

The invitation for participation in the survey In Croatia was sent to potential participants through official mailing lists of key institutions such as Ministry of tourism, Ministry of Environment and Energy and Croatian Institute of Public Health. Such dynamics and support of governmental institution was previously assured by Croatian team members. Also, all the aspects of the study were approved by the Ethical committee of the Institute of Social Sciences Ivo Pilar where two out of three Croatian team members are currently employed.

Altogether, a group of 600 respondents was targeted in Croatia of which roughly 350 from tourism domain, 220 from public health domain and 30 from nature protection. A total of 112 respondents completed Croatian questionnaire (82 female and 31 male; $40 \%$ aged $31-41,29 \%$ aged $42-52,19 \%$ aged $53-63$ and $12 \%$ aged $18-31 ; 70 \%$ with MA/MS degree), out of which 15 were from the environment/nature protection sector, 42 from public health sector and 56 from tourism/recreation sector. The received number of completed questionnaire met the working group requirements for the country and was sufficient for the analysis presented below.

\section{Results and discussion}

With regard to first hypothesis looking at familiarity with the concept of ecosystem services, qualitative insights suggested that respondents from tourism and environment/nature protection seemed to be more acquainted with the concept of ecosystem services that the respondents from the public health domain. This suggestion was corroborated by quantitative analysis which showed that there were differences in familiarity with ecosystem services between professionals employed in all chosen sectors $\left(\chi^{2}=15.98, \mathrm{df}=2, \mathrm{p}<.001\right)$. Nearly all respondents from environment/ nature protection domain stated that they were familiar with the ecosystem concept, more respondents from tourism/recreation stated they were familiar than that they weren't, while nearly twice more respondents from public health state they were not familiar than that they were.

Table 1.

Familiarity with ecosystem services concept

\begin{tabular}{|l|c|c|}
\hline \multirow{2}{*}{ Domain } & \multicolumn{2}{|c|}{$\begin{array}{c}\text { Were you previous to this questionnaire familiar with the } \\
\text { concept of Ecosystem services? }\end{array}$} \\
\cline { 2 - 3 } & $\mathrm{N}$ & Y \\
\hline Environment/Nature protection & 1 & 14 \\
\hline Public Health/Well-being & 27 & 15 \\
\hline Tourism/Recreation & 22 & 34 \\
\hline Total & 50 & 63 \\
\hline
\end{tabular}

Source: Research, 2016. 
In Croatia, obviously, there are differences in familiarity with ecosystem services concept across domains of interest. Respondents from environment protection and tourism are more familiar with the concept than respondents from public health domain. This is contrary to the hypothesis which suggested that respondents from public health and environment protection domains would be more familiar than respondents from tourism domain. Given the fact public health greatly depends of the "health" of ecosystem services (McMichael, 1993; Rapport, Costanza and McMichael, 1998), an increase of the familiarity with the concept within the public health institutional system in Croatia should be of general (public) interest.

When it comes to second hypothesis related to the relevance of the concept of ecosystem services for work, the results obtained from qualitative research did not enable us to draw any specific conclusion as respondents were not keen to clearly answer this question. However, quantitative analysis showed that there were differences between professionals employed in all three domains in assessments of relevance of ecosystem services for their work $\left(\chi^{2}=10.13, \mathrm{df}=2, \mathrm{p}=.006\right)$. While the opinion of respondents from the public health domain is divided, respondents from both tourism/recreation and especially environment/nature protection rate ecosystem services as relevant for their work.

Table 2.

Relevance of the concept of ecosystem services to your work

\begin{tabular}{|l|l|c|c|}
\hline \multicolumn{2}{|c|}{} & \multicolumn{2}{|c|}{$\begin{array}{c}\text { Do you consider the concept of Ecosystem services } \\
\text { relevant to your work? }\end{array}$} \\
\cline { 3 - 4 } \multicolumn{2}{|c|}{} & N & Y \\
\hline \multirow{3}{*}{ Field } & Environment/Nature protection & 2 & 13 \\
\cline { 2 - 4 } & Public Health/Well-being & 20 & 22 \\
\cline { 2 - 4 } & Tourism/Recreation & 12 & 44 \\
\hline Total & 34 & 79 \\
\hline
\end{tabular}

Source: Research, 2016.

These results confirm the second hypothesis as it is clearly shown that respondents from nature protection and tourism (which were more familiar with the concept of ecosystem services) indeed considered them as being relevant for their work, and that was probably the reason for which they were familiar with the concept in the first place. Also, it is interesting to observe that respondents from public health sector domain divide on the notion of relevance of the ecosystem services concept for their work. Even though results presented in Table 1 show a low familiarity with the concept within the public health institutional network in Croatia, results presented in Table 2 stress that a significant number of respondents within this domain consider the concept relevant for their work. This insight suggests a need for further research on the awareness about this concept within the public health domain in Croatia. 
Figure 1.

Perception of importance of specific ecosystem service by respondents from environment, public health and tourism domains in Croatia

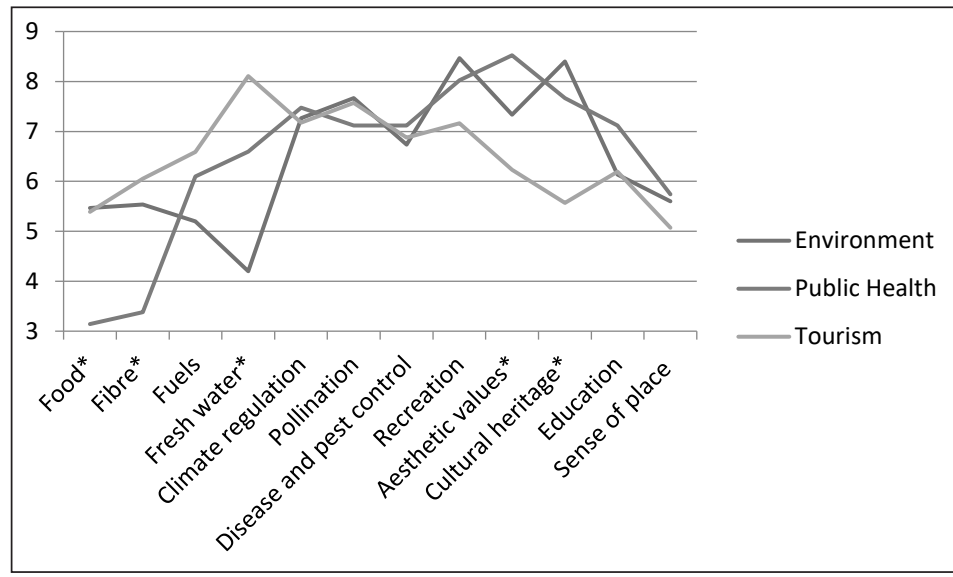

Source: Research, 2016.

In order to test the third hypothesis related to the perceptions of importance of ecosystem services across relevant institutional domains, respondents were asked to rank twelve ecosystem services present in enclosed farm habitat (Smith et al., 2013) ${ }^{6}$. The analysis showed that there were differences between domains in rankings of specific ecosystem services according to their importance within national context: respondents from public health sector perceived food as more important than the respondents from the other two sectors $(\mathrm{F}(2,110)=7.12, \mathrm{p}<.001)$, respondents from environment sector ranked fresh water as more important than the respondents from the other two sectors $(\mathrm{F}(2,110)=11.03$, $\mathrm{p}<.001)$, while respondents from tourism sector ranked cultural heritage as more important than the respondents from the other two sectors $(\mathrm{F}(2,110)=8.49, \mathrm{p}<.001)$. Moreover, respondents from tourism sector rank aesthetic values as more important than respondents from public health sector $(\mathrm{F}(2,110)=8.18, \mathrm{p}<.001)$, while respondents from public health rank fibre as more important than respondents from tourism sector $(F(2,110)=6.72, p<.01)$.

With regard to the fourth hypothesis inquiring about the domain to which respondents would allocate the responsibility for the implementation of policies on ecosystem services, quantitative analysis showed that there were differences between domains $\left(X^{2}=29.02, d f=4, p<.001\right)$. Although most of the respondents suggested that the agent should be from the environment and nature protection field, there is also significant share of respondents from each domain that believe the agent should be from their respective field.

$\mathbf{6}$ This question was not the part of qualitative research, so only quantitative analysis of responses is available for interpretation. 
Table 3.

Agent responsible for policies on Ecosystem services in Croatia

\begin{tabular}{|l|l|c|c|c|}
\hline \multicolumn{2}{|c|}{} & \multicolumn{2}{|c|}{$\begin{array}{l}\text { In your opinion from which institutional field should be an agent } \\
\text { principally responsible for policies on Ecosystem services in your } \\
\text { NUTS 2 level region? }\end{array}$} \\
\cline { 3 - 5 } & $\begin{array}{c}\text { Environment and } \\
\text { nature protection }\end{array}$ & $\begin{array}{c}\text { Public Health / } \\
\text { Well-being }\end{array}$ & \multicolumn{2}{c|}{$\begin{array}{c}\text { Tourism / } \\
\text { Recreation }\end{array}$} \\
\hline \multirow{2}{*}{ Field } & $\begin{array}{l}\text { Environment/Nature } \\
\text { protection }\end{array}$ & 13 & 0 & 2 \\
\cline { 2 - 5 } & Public Health/Well-being & 14 & 18 & 6 \\
\cline { 2 - 5 } & Tourism/Recreation & 32 & 4 & 2 \\
\hline Total & & 59 & 22 & 25 \\
\hline
\end{tabular}

Source: Research, 2016.

Clearly, respondents in Croatia primarily allocate governance responsibility over ecosystem services to the domain of environment and nature protection. It should therefore be of interest to further investigate what kind of governance capacity should be developed in the Ministry of Environment and Energy in Croatia, which would more closely cooperate with public health and tourism domain. This becomes relevant as a number of respondents allocate responsibility for the policies related to ecosystem services in other two respective domains.

Respondents from tourism and nature protection domains assessed the concept of ecosystem services as relevant for their work as it was shown in Table 2 . The testing of the fifth hypothesis related to the evaluation of the existing cooperation between institutions related to environment, public health and tourism showed expected result. In the qualitative survey all respondents agreed there was cooperation between institutions that was of a key importance for the country, but it should be enhanced. Further, quantitative analysis corroborated and strengthened the qualitative insight as it showed no differences between sectors $\left(X^{2}=5.32, d f=6, p=.504\right)$. Most of respondents rated the cooperation as unsatisfactory.

Table 4.

Evaluation of cooperation related to environment, public health and tourism in Croatia

\begin{tabular}{|l|c|c|c|c|}
\hline \multirow{2}{*}{ Domain } & \multicolumn{4}{|c|}{$\begin{array}{c}\text { Please evaluate the actual cooperation of institutions related to } \\
\text { environment, public health and tourism within your country? }\end{array}$} \\
\cline { 2 - 5 } & Satisfactory & I don't know & Unsatisfactory & It doesn't exist \\
\hline Environment/Nature protection & 3 & 1 & 11 & 0 \\
\hline Public Health/Well-being & 6 & 12 & 22 & 2 \\
\hline Tourism/Recreation & 10 & 17 & 26 & 3 \\
\hline Total & 19 & 30 & 59 & 5 \\
\hline
\end{tabular}

Source: Research, 2016. 
Finally, when quantitatively testing the sixth hypothesis, assuming that respondents from the nature protection field will favor higher level of authority (i.e. EU) when it comes to governance of the ecosystem services policies, while the respondents from the other fields would stick to the national level, the analysis showed that there were no differences in favoring specific levels of authorities between respondents from various fields $\left(\mathrm{X}^{2}=10.81, \mathrm{df}=6, \mathrm{p}=.094\right)$, although there is a trend: public health prefers national and regional, and tourism prefers regional. Also, it is obvious that majority of respondents do not opt either for European or for local level of governance of ecosystem services.

Table 5.

Designating appropriate governance level to oversee Ecosystem services policies

\begin{tabular}{|l|l|c|c|c|c|}
\hline \multicolumn{2}{|c|}{} & \multicolumn{4}{|c|}{$\begin{array}{c}\text { In your opinion which governance level is most appropriate to } \\
\text { oversee Ecosystem services policies? }\end{array}$} \\
\cline { 3 - 6 } \multicolumn{2}{|c|}{} & European & $\begin{array}{c}\text { National/ } \\
\text { Federal }\end{array}$ & Regional & $\begin{array}{c}\text { Local } \\
\text { (municipal) }\end{array}$ \\
\hline \multirow{3}{*}{ Field } & Environment/Nature protection & 5 & 3 & 5 & 0 \\
\cline { 2 - 6 } & Public Health/Well-being & 7 & 14 & 12 & 7 \\
\cline { 2 - 6 } & Tourism/Recreation & 8 & 12 & 30 & 6 \\
\hline \multirow{2}{*}{ Total } & 20 & 29 & 47 & 13 \\
\hline
\end{tabular}

Source: Research, 2016.

Clearly, when it comes to governance issues respondents in Croatia tend to stick to the traditional governance levels, even though one would expect that the implicit understanding that most of ecosystem services are public goods (Fisher et al., 2008) and that most of the problems related to ecosystem services are transboundary (Dietz, Ostrom, Stern, 2003) and thus distributed across more than one country should imply greater focus on common European governance.

\section{Conclusion}

The analysis presented above pointed to some interesting results. First, there is an encouraging familiarity with ecosystem services concept within tourism and environment protection domains in Croatia. Such an institutional awareness could be seen as positive finding in the times when Croatia is becoming a leading European tourism destination because it might suggest capacity for developing sustainable tourism development policies. On the other hand, there is a rather surprising unfamiliarity with the ecosystem services concept within public health domain in Croatia. It would certainly be of public interest to increase the level of understanding of the concept within this particular domain in Croatia as evidence about interdependence of the "health" of ecosystem services and public health globally grows. Further, a very encouraging result is the significant perception of relevance of ecosystem services concept within tourism and nature protection domains because it could 
suggest that in Croatia there is institutional capacity to expand the understanding of the concept even though the country has accessed to the EU only in 2013. Also, it is interesting to observe that public health domain has a divided opinion on the relevance which comes as an encouraging twist after a low level of familiarity with the concept has been observed within this domain in the Table 1. Since nature protection respondents choose water, public health respondents choose food and fibre while tourism respondents choose cultural heritage and aesthetic values as most important ecosystem services on national territory; it is rational to conclude that the professional and institutional affiliation of respondents does affect the perception of the importance of various ecosystem services in Croatia. Bearing in mind that respondents from all three domains label the cooperation within their respective domains as unsatisfactory while suggesting that the most appropriate governance agent for the issues related to ecosystem services should be from the environment and nature protection domain, it could be proactive to focus on those, most important ecosystem services in defining the channels of governance cooperation between three now separated public sector domains. Finally, more efforts should be directed across all three domains into explaining non-local and trans border character of ecosystem services as the results indicate that most of the respondents choose honor traditional governance levels: national and regional more that European and local.

Methodological limitations to this research are obvious. First, the sample was nonprobabilistic, although it targeted the population of people that monitor and/or regulate tourism, public health and nature protection issues in an institutionally organized manner. However, conclusions derived from this research should be re-tested on a probabilistic sample. Second, the participation in the research was compulsory both by working group members and by targeted respondents. Such compulsory frame of the research made the process of designing and disseminating the questionnaire in particular EU country targeted by the research (within a very limited time span) a very challenging task. For these two reasons the conducted research can be considered as a country level pilot study which could serve as a strong base for more robust future studies that could be developed on EU level, on the basis of this pilot-project.

\section{References}

1. Blanco, E. and Razzaque, J. (2009). Ecosystem Services and Human Well-Being in a Globalized World: Assessing the Role of Law. Human Rights Quarterly, 31 (3): 697-720.

2. Boerema, A.; Rebelo, A. J.; Bodi, M. B.; Esler, K. J.; Meire, P.; Rohr, J. (2017). Are ecosystem services adequately quantified?. Journal of Applied Ecology, 54: 358-370.

3. Boyd, J. and Banzhav, S. (2007). What are ecosystem services? The need for standardized environmental accounting units. Ecological Economics, 63 (2-3): 616-626.

4. Capak, K. and Petrović. G. (2009). Environmental health in Croatia - current status and perspectives. Periodicum biologorum, 111 (1): 13-19. 
5. COST (2012). Memorandum of Understanding for the implementation of a European Concerted Reserach Action designated as COST ACTION IS 1204: Tourism, Wellbeing and Ecosystem Services (TobeWELL). Brussels: COST CSO.

6. Cro. EPA - Environmental Protection Agency, Republic of Croatia, 2008. National List of Tourism Indicators (Nacionalna lista pokazatelja za turizam). Br. Dok.: 25-08-82/11. Zagreb, 08. 02. 2008. Agencija za zaštitu okoliša. www.azo.

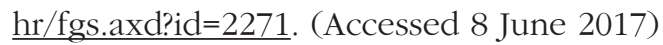

7. Cvjetanović, B. (1990). Hommage to Andrija Stampar. World Health Forum, vol. 11: 376-380.

8. Čorak S. and Boranić-Živoder S. (2017). Tourism Destination and DMO Transformation, in: Dwyer L.; Tomljenović R. and Čorak S. (Eds.). Evolution of Destination Planning and Strategy: The Rise of Tourism in Croatia. Springer: 99-119.

9. Dietz, Th.; Ostrom, E. and Stern, C. P. (2003) The Struggle to Govern the Commons. Science, 303 (5652): 1907-1912.

10. Dwyer, L.; Tomljenović, R. and Čorak, S. (2017). Evolution of Destination Planning and Strategy - The Rise of Tourism in Croatia. Palgrave Macmillan.

11. European Commission (2017). Natura 2000. http://ec.europa.eu/environment/ nature/natura2000/index_en.htm. (Accessed 13 June 2017)

12. Fisher, B., et al. (2008). Ecosystem Services and Economic theory: Integration for Policy-Relevant Research. Ecological Applications, 18 (8): 2050-2067.

13. Gemenne, F.; Bruckner, P. and Ionesco, D. (2013). The State of Environmental Mirgration. Paris: IDDRI. http://www.iddri.org/Publications/Collections/Analyses/SEM\%202013.pdf. (Accessed 29 May 2017)

14. GOC - Government of Croatia (2017). Proposal of the Strategy and Action plan of Nature Protection 2017 - 2025. (Nacrt prijedloga strategije i akcijskog plana zaštite prirode Republike Hrvatske za razdoblje od 2017. do 2025. godine). https:// vlada.gov.hr/UserDocsImages//Sjednice/2017/02\%20velja\%C4\%8Da/20\%20sjednica\%2014\%20VRH//20\%20-\%2011\%20b.pdf. (Accessed 1 June 2017)

15. Grêt-Regamey A.; Sirén E.; Brunner S. H.; Weibel B. (2017), Review of decision support tools to operationalize the ecosystem services concept. Ecosystem Services, 26: 306-315.

16. Haase, D.; Frantzeskaki, N. and Elmquist, Th. (2014). Ecosystem Services in Urban Landscapes: Practical Applications and Governance Implications. Ambio, 43 (4): 407-412. https://www.ncbi.nlm.nih.gov/pmc/articles/PMC3989513/. (Accessed 30 May 2017)

17. Institute for tourism (2015). Attitudes and spendings of tourists in Croatia - TOMAS summer 2014. Zagreb.

18. Ivandić N. and Marušić Z. (2017). Implementation of tourism satellite account: Assessing the Contribution of Tourism to the Croatian Economy, in: Dwyer L.; Tomljenović R. and Čorak S. (Eds.). Evolution of Destination Planning and Strategy: The Rise of Tourism in Croatia. Springer: 149-173.

19. Kranjčević J. (2017). Abandoned Tourism Resorts in Croatia: The Consequence of Discordant Spatial Planning and Tourism Development Policies, in: Dwyer L.; Tomljenović R. and Čorak S. (Eds.). Evolution of Destination Planning and Strategy: The Rise of Tourism in Croatia. Springer: 173-201. 
20. Kunst I. (2017). Managing Tourism Development Process in Croatia: Can European Union Accession Help?, in: Dwyer L.; Tomljenović R. and Čorak S. (Eds.). Evolution of Destination Planning and Strategy: The Rise of Tourism in Croatia. Springer: 37-67.

21. Kušen E. (2017). Tourism Attraction System, in: Dwyer L.; Tomljenović R. and Čorak S. (Eds.). Evolution of Destination Planning and Strategy: The Rise of Tourism in Croatia. Springer: 119-149.

22. Leimona B.; van Noordwijk M.; de Grot R.; Leemans R. (2015). Fairly efficient, efficiently fair: Lessons from designing and testing payment schemes for ecosystem services in Asia. Ecosystem Services, 12: 16-28.

23. Lugo, E. (2008). Ecosystem services, the Millennium Ecosystem Assessment and the Conceptual Difference Between Benefits Provided by Ecosystems and Benefits Provided by People. Journal of Land Use E Environmental Law, 23 (2): 243-261.

24. McMichael, A. J. (1993). Planetary Overload: Global Environmental Change and the Health of the Human Species. Cambridge University Press.

25. MENP - Ministry of Environmental and Nature Protection (2017). History of nature protection in the Republic of Croatia. http://www.zastita-prirode.hr/eng/ Protected-Nature/Nature-protection-in-the-Republic-of-Croatia/History-of-nature-protection-in-the-Republic-of-Croatia. (Accessed 9 June 2017)

26. Ministry of Health (2012). National Health Care Strategy, Abridged Version. Zagreb.

27. Notman, E., et al. (2006). State of Knowledge: Ecosystem Services from Forests. http://www.fs.fed.us/ecosystemservices/pdf/state-of-knowledge.pdf. (Accessed 9 June 2017)

28. Ozimec, R. (2014). Ecological tourism in: Matić et al. (Eds). Irrisistible Croatia (Neodoljiva Hrvatska). Zagreb: Lux Promocija.

29. Pearce, D. (2007). Do we really care about Biodiversity? Environmental Resource Economics, 37 (1): 313-333.

30. Posner S.; McKenzie E. and Ricketts T. (2016). Policy impacts of ecosystem services knowledge. Proceedings of the National Academy of Sciences of the United States of America (PNAS), 113 (7): 1760-1765. http://www.pnas.org/content/113/7/1760. (Accessed 23 May 2018)

31. Poljanec-Borić, S. (2016). Pravo na sada (The Right to Now). Zagreb: Institut društvenih znanosti Ivo Pilar.

32. Primmer, E.; Jokinen, P.; Blicharska, M.; Barton, N. D.; Potschin, M. (2015). Governance of Ecosystem Services: A framework for empirical analysis. Ecosystem services, 16: 158-166.

33. Rapport, J. D.; Costanza, R. and McMichael, A. J. (1998). Assessing ecosystem health. Trends in Ecology and Evolution, 13 (10): 397-402.

34. Ruijs, S. and van Egmond P. (2017). Natural capital in practice: How to include its value in Dutch decision-making processes. Ecosystem services, 25, June: 106-116.

35. Salzman, J. E. (2006). A Field of Green: The Past and Future of Ecosystem Services. Journal of Land Use E Environmental Law, 21 (2): 133-151.

36. Smith, S.; Rowcroft, P.; Evarard, M.; Couldric, L.; Reed, M.; Roger, H.; Quick, T., Eves, C.; White, C. (2013). Payments for Ecosystem Services: A Best Practice Guide. London: Defra. 
37. The Nation (2005). Post-Tsunami tourism Phuket struggles to reverse slump. http://www.thaiwebsites.com/tourism-tsunami.asp. (Accessed 7 June 2017)

38. University of Zagreb (2017). School of Public Health Andrija Stampar. http:// mef.unizg.hr/en/about-us/organisation/school-of-public-health-andrija-stampar. (Accessed 7 June 2017)

39. Vukonić, B. (2005). Povijest hrvatskog turizma. Prometej.

40. WEF - World Ecoomic Forum (2017). The Travel \& Tourism Competitiveness Report 2017. Paving the way for a more sustainable and inclusive future. ISBN-13: 978-1-944835-08-8. Geneva.

41. World Resource Institute (2005). Millenium Ecosystem Assessment, Ecosystems and Human Well-Being: Synthesis. http://www.millenniumassessment.org/documents/document.356.aspx.pdf. (Accessed 7 June 2017) 
Izvorni znanstveni rad

Saša Poljanec-Borić

Institut društvenih znanosti Ivo Pilar, Zagreb, Hrvatska

e-mail:sasa.boric@pilar.hr

\title{
Anja Wertag
}

Institut društvenih znanosti Ivo Pilar, Zagreb, Hrvatska

e-mail:anja.wertag@pilar.hr

Hrvoje Carić

Institut za turizam, Zagreb, Hrvatska

e-mail: hrvoje.caric@iztzg.hr

\section{Percepcija ekosistemskih usluga u institucijama javnog zdravstva, turizma $i$ zaštite okoliša u Hrvatskoj}

\begin{abstract}
Sažetak
U članku se analizira koliko je koncept ekosistemskih usluga prepoznat u različitim institucijama javnog sektora u Hrvatskoj te kakva je percepcija ili stav o njima. Ispitanici su zaposleni u javnim ustanovama u zdravstvu, turizmu i zaštiti okoliša/prirode. Prema COST-ovom projektu TObeWELL izrađen je upitnik o viđenju ekosistemskih usluga unutar tih ustanova u nekoliko zemalja Europske unije, uključujući Hrvatsku. Ispitivanje metodom namjernog uzorka u Hrvatskoj pokazuje da je u turizmu i zaštiti okoliša poznavanje ekosistemskih usluga zadovoljavajuće, ali je nezadovoljavajuće u institucijama javnog zdravstva. Međutim u svim spomenutim područjima ekosistemske usluge prepoznate su kao relevantne, iako je suradnja u upravljanju tim uslugama u zdravstvu, turizmu i zaštiti okoliša ocijenjena nezadovoljavajućom.
\end{abstract}

Ključne riječi: ekosistemske usluge, javno zdravstvo, prirodni okoliš, turizam, politika upravljanja. 